\title{
WHAT MAKES A HEALTHY ENVIRONMENT FOR NATIVE FRESHWATER MUSSELS?
}

\section{What are freshwater mussels, and what makes them special?}

Freshwater mussels are mollusks-close relatives of clams, oysters, and saltwater mussels. Many species of freshwater mussels can live for 20 to 30 years, and individuals of some species live for more than 100 years. Freshwater mussels have been valued by humans throughout history. They can produce pearls, and their shells can be used to make buttons for clothing or to serve as seedstock for the cultured pearl industry. In past times, freshwater mussels also were food for Native Americans.

Freshwater mussels are sensitive to contamination of sediment that they inhabit and to the water that they filter, making the presence of live, adult mussels an excellent indicator of ecosystem health and stability. Freshwater mussels are relatively immobile, imbedded in the streambed with part of their shell sticking up into the water so that they can filter water to obtain oxygen and food. This lack of mobility makes them particularly vulnerable to water and sediment contamination, changes in sedimentation, or prolonged drought. Thus, ecosystem health and stability are critical for their reproduction and survival.

Freshwater mussels are among the most endangered groups of animals in North America. Human influences - such as agricultural practices, construction of dams, and urban sprawl-have altered river flows, water quality, fish populations, and other environmental factors that are essential for the survival of freshwater mussels. These influences have contributed to the continuing decline of freshwater mussels throughout the United States (National Native Mussel Conservation Committee, 1998).

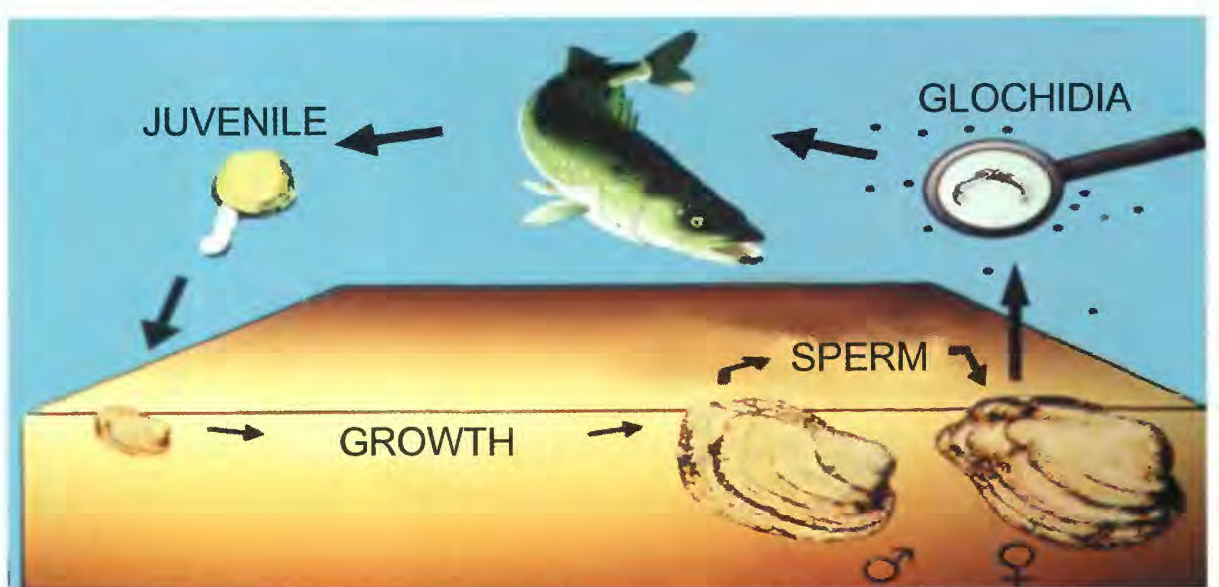

Figure 1. Life cycle of freshwater mussels. After fertilization of eggs (lower right corner), glochidia, or larvae, are released. Those glochidia that successfully attach to fish hosts transform into juvenile mussels, which detach and burrow into the streambed. (Diagram by G.T. Watters, Ohio State University.)

Attempts are being made to restore native-mussel populations in areas where reintroduction has a chance for success. The success of these attempts, however, will depend on whether physical habitat and other environmental factors are favorable for the mussels to survive and reproduce. As yet, researchers and biologicalresource managers know little about which environmental factors have the most significant effects on mussel communities or how various environmental factors interact to support or harm mussels at various stages of life.

\section{Where are freshwater mussels found?}

Although freshwater mussels are found throughout much of the world, the highest freshwater-mussel diversity on Earth is in North America (Stansbery, 1970). For example, a single stream - Big Darby Creek, in central Ohio - historically contained 42 species of unionid mussels, more species than in all of Australia and Europe combined. Live freshwater mussels are not often seen because they are partly buried in the sediments of creeks, rivers, and lakes. The empty shells of dead mussels, however, can be found on the stream bottom and along the edge of water, especially if predators such as muskrats, otters, and raccoons are feeding in the area.

\section{What is the life cycle of freshwater mussels?}

The life cycle of North American freshwater mussels is unusual among aquatic animals because it usually requires fish as intermediate hosts for mussel larvae (fig. 1). Freshwater mussels are conceived when male mussels release sperm into the water and the eggs of nearby females are fertilized. The fertilized eggs of the female develop into larvae (glochidia), which are released into the water in ways that have evolved to attract host fish (fig. 2). If a larva attaches to a fish, it will ingest cell fluid of the fish for nutrition; after a period of several hours to several weeks (depending on water temperature and species), the larva will transform to a juvenile, drop off the fish, and burrow into streambed sediment with its foot (fig. 1). The proportion of released larvae that actually attach to host fish and survive to inhabit the streambed is minute, estimated at anywhere from 1 in a million to 1 in 100 million (Watters, 1995). 


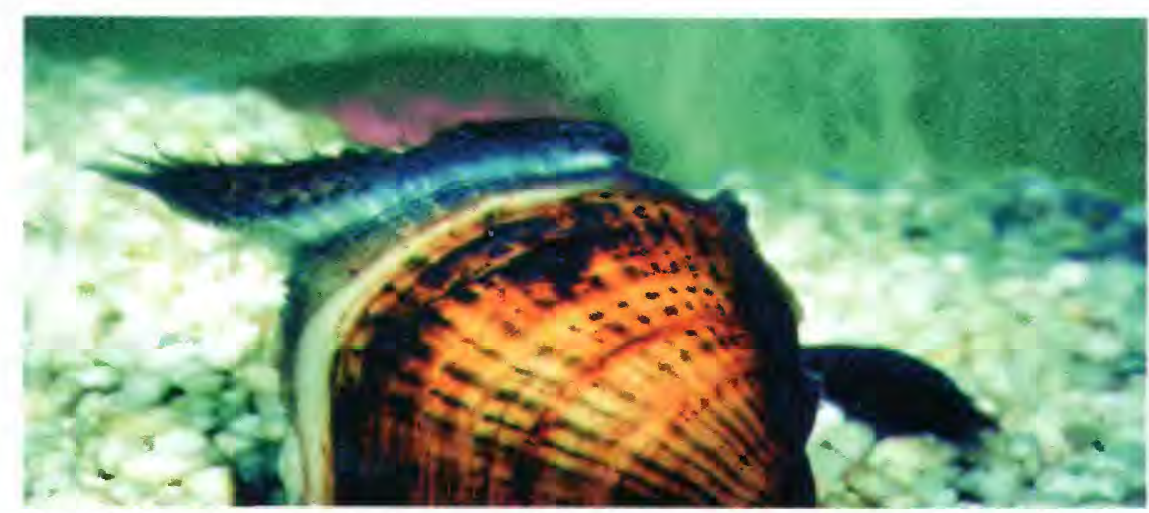

Figure 2. Female mussel displaying mantle to attract a fish host. Predator fish lured by the prey-like appearance of the mantle come close to where glochidia are released, and some glochidia may successfully attach. (Photo by G.T. Watters, Ohio State University.)

\section{What factors influence success during life stages of freshwater mussels?}

Each life stage for freshwater mussels has specific environmental requirements:

Adults - Adequate water quantity and quality, a stable stream channel, adequate sediment quality, food, protection from predators, and sufficient population densities for fertilization.

Larvae (Glochidia) - Availability of fish host upon which to attach, for nourishment and dispersal.

Juveniles - Same as adults; however, because a juvenile gathers food particles by extending its foot into the streambed, it is more sensitive to sediment contamination than the adults that feed by filtering the surrounding water.

One approach toward clarifying the relations between environmental factors and healthy native-mussel communities is to locate a particular stream where nativemussel populations are known to exist, then

- compile an inventory of native freshwater-mussel species that have been found previously,

- follow with an evaluation of current populations, and

- collect data on possible positive and negative factors contributing to the survival of native freshwater mussels, using conventional waterand sediment-quality analyses and ecological-assessment tools.
For example, the U.S. Geological Survey (USGS)-in cooperation with the U.S. Environmental Protection Agency, Ohio Environmental Protection Agency (Ohio EPA), Indiana Department of Natural Resources (IDNR), Allen County (Indiana) Soil and Water Conservation District (SWCD), The Nature Conservancy, Ohio Department of Natural Resources (ODNR), and The Ohio State University-did a study of this kind in the St. Joseph River Watershed in Indiana, Michigan, and Ohio. (See inset box describing this study.) The purpose of this study was to gather information on mussel-population viability and suitability of stream sites for mussels, information that could potentially help in efforts to restore native-mussel populations in this watershed and perhaps elsewhere in the United States. Thirty-six species of freshwater mussels had previously been found in the St. Joseph River Watershed, 30 of them occurring in Fish Creek, including the Federally endangered white catspaw (fig. 3), clubshell, and northern riffleshell (Watters, 1988, 1995, 1998). A composite view of a site on Fish Creek is shown in figure 4.

The following paragraphs list some of the environmental factors that can be studied; results from work in the St. Joseph Watershed are given in the inset section.

Water quantity. For a particular stream site or reach to be suitable habitat for mussels, the stream bottom must not go dry. Thus, an adequate amount of base flow-that part of streamflow that is sustained by ground-water discharge to the stream-is crucial. Ground-water dis- charge helps to moderate seasonal changes in streamflow and water temperature, dilute contaminants in surfacewater runoff, and help mussels survive drought. Base flow can be determined by analyzing long-term streamflow records, if available, and/or by making special streamflow measurements during a dryweather period.

Water and sediment quality. Because adult mussels are filter feeders, they are sensitive to waterborne contaminants such as those carried in agricultural runoff and in municipal and industrial wastewater. Juvenile mussels, on the other hand, may be particularly sensitive to the chemistry of the sediments in which they live and feed. Thus, possible influences on mussel communities include not only the chemical quality of streamwater but also the chemical quality of streambed sediments, which are particularly prone to storing trace metals and organic chemical compounds. Water and sediment quality can be evaluated from a combination of onsite measurements of water quality and collection of water and sediment samples for laboratory analyses.

Stream-channel stability. A stable stream channel is favorable for freshwater mussels because it provides a secure dwelling area and promotes water clarity. In unstable channels, movement of streambed sediment due to high flows often leaves mussels either buried too deeply in sediment or stranded on sand or gravel bars, exposing the mussels to air and predators when streamflows are low. Moreover, unstable channels are prone to producing excessive suspended sediment that can clog the mussels' gills (Strayer,

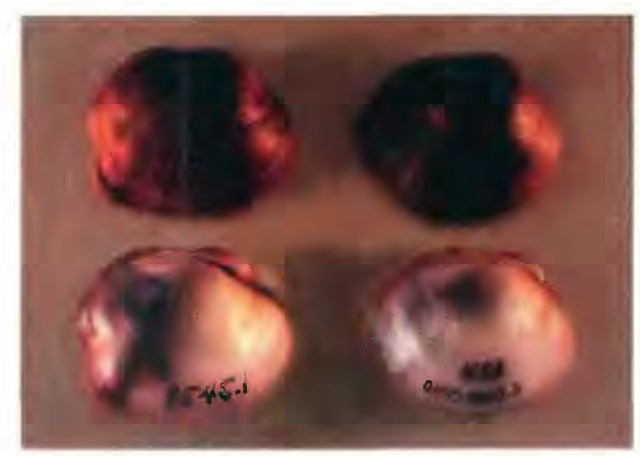

Figure 3. Specimens of white catspaw mussel, Epioblasma obliquata perobliqua (Conrad, 1836). This very rare mussel species is on the Federal endangered species list. (Photo by G. T. Watters, Ohio State University.) 


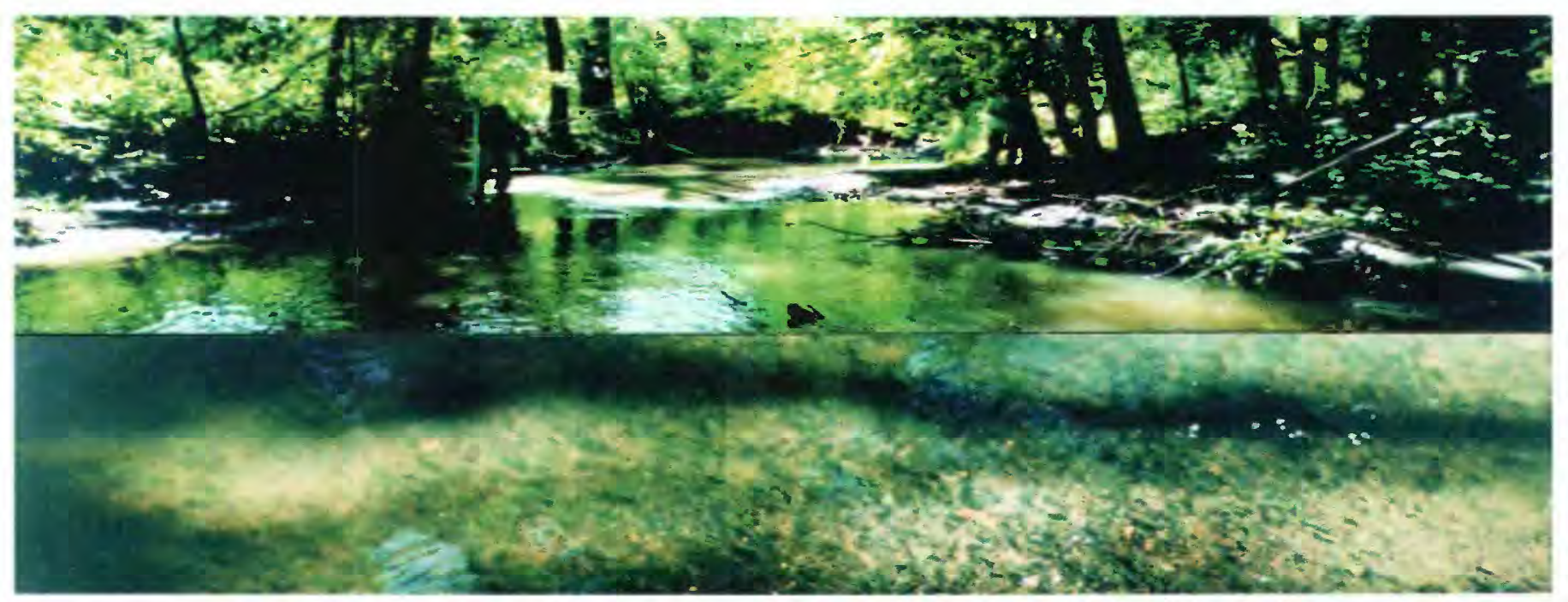

Figure 4. Composite view of surface and subsurface characteristics, Fish Creek near Alvarado, Ind. (site 8 on fig. 5). Environmental factors favorable for native freshwater mussels include a forested buffer along the streambanks and a gravel streambed with a moderate cover of silt.

1999a). Stream channels can be described by means of stream-habitat assessment procedures, such as the Qualitative Habitat Evaluation Index (QHEI) developed by Ohio EPA (Rankin, 1989).

Fish. Although fish can be a negative influence on mussel communities because of predation (see next paragraph), host species of fish must be present for most mussels to be able to reproduce and disperse. Known or suspected fish hosts can be inventoried at a site by way of electrofishing surveys or other means of fish-population assessment.

Predation. Humans have caused a dramatic decline in mussel populations by harvesting them for natural pearls, buttons, and seed stock for the cultured pearl industry. Other predators include muskrats, raccoons, some duck species, and some fish species. Predation can be assessed only indirectly, by examining records of poaching (humans) or looking for piles of empty shells on the streambank, especially in the spaces between roots of large trees (animals).

Exotic species. Species that invade from outside their original ranges have strongly affected the distribution and abundance of native freshwater mussels and their native mollusk relatives in North America (National Native Mussel Conservation Committee, 1998). The zebra mussel (Dreissena polymorpha), for example, is native to Europe and Asia. In North America, it attaches and grows over the freshwater mussels, competing for food and oxygen. The presence of exotic mussel species can be identified by examination of the streambed and streambanks.

\section{How can information on these environmental factors help in protecting and restor- ing mussel populations?}

If potential positive and negative environmental factors of a current or potential mussel habitat can be identified by means of scientific study, then biological-resource managers can begin to evaluate management strategies for trying to preserve or restore native-mussel populations.

In the St. Joseph River Watershed, for example, study results indicate that the strong environmental qualities of the watershed (adequate dry-weather streamflow, stable stream channels, and presence of host fish) should be incorporated in a preservation/restoration design to minimize or reduce environmentalquality concerns. Specific environmentalquality concerns for preservation and restoration include

- uncertainty about survival rates of young mussels in contaminated sediments,
- effects of wastewater discharges (contributing to the elevated concentrations of phosphorus, algal chlorophyll $a$, and bacteria),

- the possibility of future habitat degradation, and

- the presence of sufficient numbers of healthy adult mussels for successful reproduction.

The factors and tools listed in this fact sheet would be a logical starting point for studies elsewhere. Additional factors and tools could be added to this approach as knowledge of native freshwater-mussel species increases (specifically, what exactly serves as food sources, and how tolerant are mussels of contaminants in water and sediments). Also beneficial would be collection of sediment-quality data and microbiological data at each site where other environmental factors are measured.

Protecting and restoring nativemussel populations is difficult if knowledge of their environmental requirements is lacking. Studies like the one done in the St. Joseph Watershed begin to build an information base that can be used to preserve a healthy native-mussel population or to restore a community in a place where native mussels have disappeared. 


\section{St. Joseph Watershed study}

Three tributaries in the St. Joseph River Watershed were chosen to characterize mussel habitat because this watershed serves as a refuge for mussel biodiversity in the Great Lakes region (Nature Conservancy, 1994). Twelve locations were studied, four on each of the three tributary streams that flow into the St. Joseph River-Cedar Creek, Fish Creek, and the West Branch of the St. Joseph River (fig. 5 ). The rich diversity of mussels ( 30 species) in such a small watershed as Fish Creek (109 square miles) has received considerable attention from those interested in preserving biological diversity in the region (Nature Conservancy, 1994). Cedar Creek, a State Scenic River in Indiana, once had a much greater diversity of mussels ( 27 species) than it does today (table 1). The West Branch headwater stream was included because of its similarity in size to the Fish Creek Watershed, the number of live mussel species found (20), and the fact that it has undergone little urban or industrial development

Number of mussels found. The number of native-mussel species found either alive or freshly dead ranged from zero (at two sites on Cedar Creek) to 16 (site 6, on Fish Creek). As an indicator of mussel-diversity decline, the number of mussels found at each of the 12 study sites was compared to records of nativemussel species recorded at that site during comprehensive surveys of mussels in the 1980's and 1990's (Hoggarth, 1987; Watters, 1988, 1996, 1998; table 1).

Base flow. For the St. Joseph Watershed study, a preliminary analysis of the long-term records of streamflows at gaging stations on Cedar and Fish Creeks (fig. 5) indicated that more than half of the annual streamflow came from ground water (57 and 67 percent of annual flow, respectively). Because no previous streamflow information was available for West Branch, a low-flow (base-flow) study was done during a summer dryweather period to compare the amount of streamflow in the three tributaries.

West Branch on average had three times the amount of ground water draining into the channel per unit area of subwatershed-about 0.46 cubic foot per second per square mile $\left(\mathrm{ft}^{3} / \mathrm{s} / \mathrm{mi}^{2}\right)$ than Fish or Cedar Creek (about $0.15 \mathrm{ft}^{3} / \mathrm{s}$ / $\mathrm{mi}^{2}$ ).

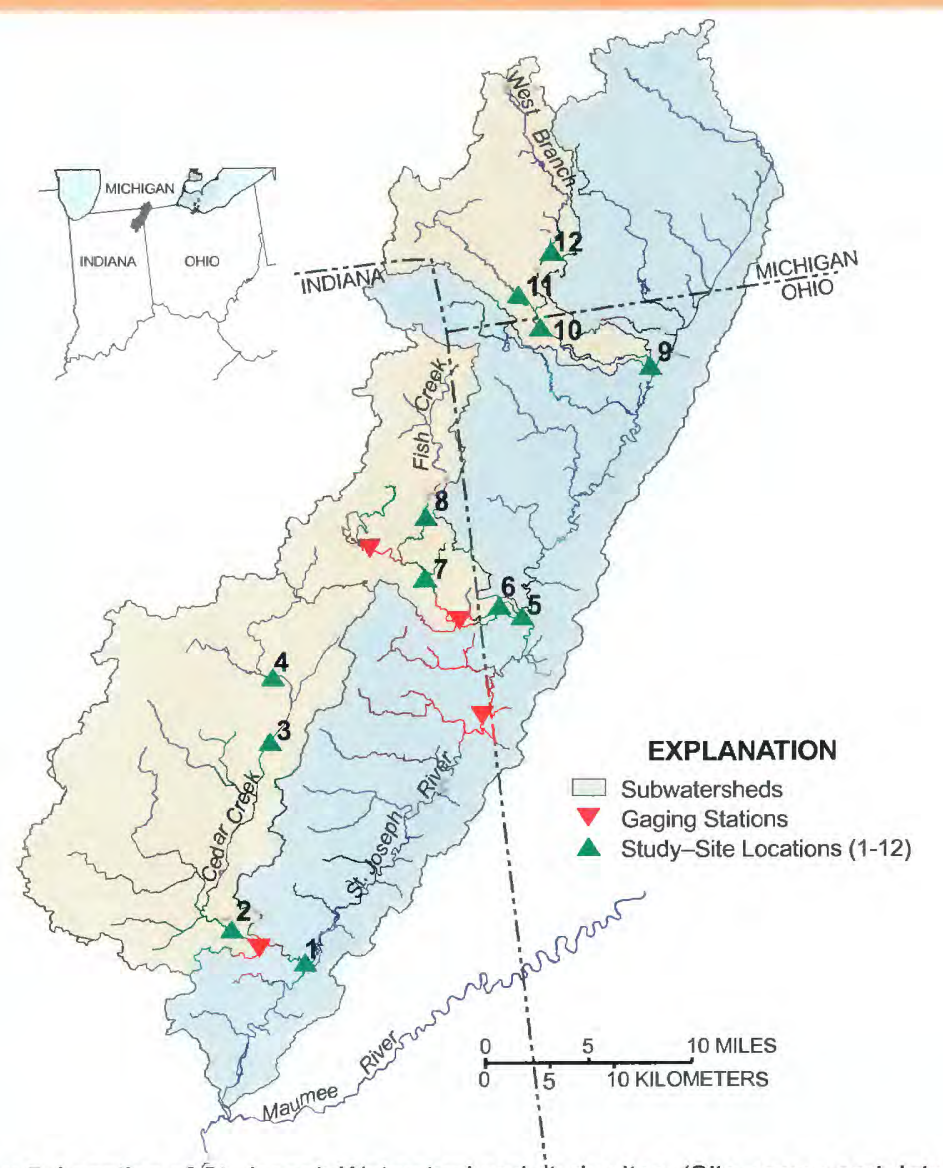

Figure 5. Location of St. Joseph Watershed and study sites. (Site names and data in table 1.)

Although Cedar Creek and Fish Creek had nearly identical flow rates, numbers of mussel species differed greatly.

In contrast, West Branch and Fish Creek had considerably different flow rates, but numbers of mussel species were similar (table 1). These findings indicate that base flows throughout the watershed were probably adequate to sustain mussel populations and that other factors were responsible for the varying numbers of mussel species found.

Water and sediment quality. Concentrations of common ions, nutrients (nitrogen and phosphorus compounds), and pesticides were determined at base flow to compare differences in water quality among sites (Shindel and others, 1999). In addition, data on trace metals and organic-chemical compounds in the streambed sediments were examined for two sites in the watershed, one each on Cedar and Fish Creeks.

Concentrations of common ions were similar among the 12 sites (Shindel and others, 1999); however, nutrient concentrations - in particular, phosphoruswere highest at the Cedar Creek sites, where the numbers of live or freshly dead mussels tended to be lowest (table 1). Phytoplankton chlorophyll $a$, a measure of the concentration of algae in streamwater, also was highest at Cedar Creek sites (table 1), likely in response to the high nutrient concentrations. In addition, concentrations of Escherichia coli (E. coli) bacteria tended to be substantially higher in Cedar Creek than in the other two tributaries (data from the Allen County SWCD, 1998; not shown). The relatively high nutrient, chlorophyll $a$, and $E$. coli concentrations raise a concern about animal waste, sewage, and other associated wastes-such as laundry detergents and pharmaceuticals-that make their way to these streams, particularly Cedar Creek. Overall, the pattern in the data indicates that sewage and (or) animal waste may be influencing Cedar Creek more than the other two streams and may be a major factor affecting mussel-community health in the St. Joseph River Watershed.

Because juvenile freshwater mussels live in and get their food from aquatic sediments, they are particularly vulnerable to contaminants in sediment. For that reason, data collected on streambed sediments from one site each on Cedar and Fish Creeks were examined for 29 con- 
Table 1. Selected mussel and environmental data collected in the St. Joseph River Watershed [Sites listed for each tributary are in order from downstream to upstream; ---, no data]

\begin{tabular}{|c|c|c|c|c|c|}
\hline $\begin{array}{l}\text { Map number and site } \\
\text { location }\end{array}$ & $\begin{array}{l}\text { Mussel } \\
\text { species }^{a}\end{array}$ & Base flow & $\begin{array}{l}\text { Total phos- } \\
\text { phorus }^{c}\end{array}$ & $\begin{array}{l}\text { Plankton } \\
\text { chloro- } \\
\text { phyll } a^{\mathrm{d}}\end{array}$ & QHEI $^{\mathrm{e}}$ \\
\hline \multicolumn{6}{|c|}{ Cedar Creek } \\
\hline 1 Near Cedarville & 4 of 26 & 0.187 & 0.119 & 9.4 & 72 \\
\hline 2 Near Robinson Chapel & 0 of 14 & .202 & .105 & 6.9 & 83 \\
\hline 3 Near Auburn & 0 of 11 & .095 & .211 & 4.2 & 49.5 \\
\hline 4 Near Waterloo & 6 of 11 & .087 & .062 & 43.7 & 45 \\
\hline \multicolumn{6}{|c|}{ Fish Creek } \\
\hline 5 At Edgerton & 8 of 12 & .185 & .062 & 3.4 & 59.5 \\
\hline 6 Near Edgerton & 16 of 22 & .174 & .072 & 2.1 & 76 \\
\hline 7 Near Edon & 10 of 15 & .117 & .064 & 2.1 & 68.5 \\
\hline 8 Near Alvarado & 6 of 11 & .097 & .051 & 1.7 & 73.5 \\
\hline \multicolumn{6}{|c|}{ West Branch } \\
\hline 9 Near Pioneer & 5 of 7 & .580 & --- & -- & --- \\
\hline 10 Near Nettle Lake & 15 of 17 & .464 & .068 & 3.9 & 75.5 \\
\hline 11 Near Austin & 6 of 12 & .395 & .083 & 3.2 & 76 \\
\hline 12 At Austin & 5 of 10 & .415 & .030 & 1.9 & 72.5 \\
\hline
\end{tabular}

a. Number of examples of live or freshly dead native-mussel species compared with total number of native-mussel species recorded during comprehensive surveys in the 1980's. Source: Watters $(1988,1998)$, plus data from this study.

b. Cubic feet per second per square mile of area contributing flow to each site. Source: Data collected for this study during a period of low flow, August 18-19, 1998.

c. Concentrations in milligrams per liter. Source: Shindel and others (1999).

d. Concentrations, in micrograms per liter, of chlorophyll $a$ in phytoplankton in the water column (free-floating algae). Source: Linda Roberts, U.S. Geological Survey, Iowa City, Iowa; extraction in September 1998, analysis in November 1998.

e. Composite scores from the Qualitative Habitat Evaluation Index (as described in Rankin, 1989). Scale is 1 to 100. Source: Data collected for this study, August 18-19, 1998.

taminants (trace elements and organic chemicals) known or suspected to be detrimental to organisms dwelling on stream bottoms (U.S. Geological Survey, 1997).

Almost one-half of the 29 contaminants in sediments in Cedar and Fish Creeks were present at concentrations exceeding the Threshold Effect Levels (TEL), guidelines based on toxicity tests with selected streambed-dwelling organisms (Ingersoll and others, 1996; Smith and others, 1996; U.S. Geological Survey, 1997). The high concentrations of some of these contaminants could be due to past industrial and municipal discharges in this area (Ohio Department of Health and others, 1953). higher means excellent habitat. In the lower part of Fish Creek, site 5 scored 59.5 because of fine-clay sediment deposition. In the upper part of Cedar Creek, sites 3 and 4 had little riparian vegetation and considerable bank erosion, reducing habitat scores to 49.5 and 45 , respectively.

The lack of correlation between the number of mussel species and QHEI scores suggests that a minimally suitable and stable channel may be necessary for freshwater-mussel survival but that good or excellent channel conditions are no guarantee of mussel-community health.

Fish. Fish surveys during 1997 and 1998 (by Ohio EPA, IDNR, and USGS) determined the availability of potential host fish living in the three St. Joseph River tributaries. Each tributary had 20 or more host fish species. Some fish species known to serve as hosts to the greatest number of mussels (8-10 mussel species) in this study were bluegill, white crappie, largemouth bass, green sunfish, and yellow perch. Because of this diversity, host-fish availability does not appear to be a limiting factor at least for common native freshwater mussels in the St. Joseph Watershed whose fish-host requirements are known.

Predation. The decline in mussels in Cedar Creek (table 1) does not appear to be due to widespread poaching or animal predation. Legislation in Indiana, Michigan, and Ohio make it illegal to collect any species of freshwater musselseither alive or dead - even with a fishing license. Ohio has now closed its waterways to all commercial musseling, and collecting for scientific purposes is allowed only under special permit through the Ohio Department of Natural Resources.

Exotic species. Although zebra mussels are documented in the St. Joseph River Watershed, they are not yet considered to be a problem. They could eventually become a problem in the watershed because control of exotic aquatic species in North America has been difficult, and attempts at control have largely been ineffective (Strayer, 1999b). 


\section{Selected references}

Havlik, M.E., and Marking, L.L., 1987, Effects of contaminants on naiad mollusks (Unionidae) - A review: U.S. Fish Wildlife Service Resource Publication 164, 20 p.

Hoggarth, M.A., 1987, The freshwater mussels (Unionidae) of the upper St. Joseph River basin within Ohio: Final report to the Division of Wildlife, Ohio Department of Natural Resources, $73 \mathrm{p}$.

Ingersoll, C.G., Haverland, P.S., Brunson, E.L., Canfield, T.J., Dwyer, F.J., Henke, C.E., Kemble, N.E., Mount, D.R., and Fox, R.G., 1996, Calculation and evaluation of sediment effect concentrations for the amphipod Hyalella azteca and the midge Chironomus riparius: Journal of Great Lakes Research, v. 22, no. 3, p. 602-623.

National Native Mussel Conservation Committee, 1998, National strategy for the conservation of native freshwater mussels: Journal of Shellfish Research, v. 17, no. 5, p. 1419-1428.

Nature Conservancy, 1994, The conservation of biological diversity in the Great Lakes ecosystem-Issues and opportunities: Chicago, Ill., The Nature Conservancy Great Lakes Program, $118 \mathrm{p}$.
Ohio Department of Health; Indiana Stream Pollution Control Board; and U.S. Department of Health, Education, and Welfare, Public Health Service, 1953, Report of water pollution study of Maumee River Basin 19501951: Ohio-Tennessee Drainage Basins Office, 90 p.

Rankin, E.T., 1989, The Qualitative Habitat Evaluation Index [QHEI] Rationale, methods, and application: Ohio Environmental Protection Agency, Division of Water Quality Monitoring and Assessment, Surface Water Section, 54 p. plus appendix.

Shindel, H.L., Mangus, J.P., and Trimble, L.E., 1999, Water resources data, Ohio, water year 1998: U.S. Geological Survey Water-Data Report OH98-2, p. 436-449.

Smith, S.L., MacDonald, D.D., Keenleyside, K.A., Ingersoll, C.G., and Field, L.J., 1996, A preliminary evaluation of sediment quality assessment values for freshwater ecosystems: Journal of Great Lakes Research, v. 22, no. 3 , p. 624-638.

Stansbery, D.H., 1970, Eastern freshwater mollusks (1) the Mississippi and the St. Lawrence River systems. Malacologia, v. 10, no. 1, p. 9-22.

Strayer, D.L., 1999a, Use of flow refuges by unionid mussels in rivers: Journal of North American Benthological Society, v. 18, no. 4, p. 468-476.
- 1999b, Effects of alien species on freshwater mollusks in North America: Journal of North American Benthological Society, v. 18, no. 1, p. 74-98.

U.S. Geological Survey, 1997, Analyses of samples collected at water-quality partial-record stations: National Water-Quality Assessment, Lake Erie-Lake St. Clair Study Unit, available at URL http://wwwoh.er.usgs.gov/nawqa/.

Watters, G.T., 1988, A survey of the freshwater mussels of the St. Joseph River system, with emphasis on the federally endangered white cat's paw pearly mussel: West Lafayette, Ind., Indiana Department of Natural Resources, $127 \mathrm{p}$.

1995, A guide to the freshwater mussels of Ohio (revised $3 \mathrm{~d}$ ed.): Ohio Department of Natural Resources, Division of Wildlife, 122 p.

1996, 1996 survey of the mussels of the Fish Creek drainage: Final report to the Indiana Chapter of The Nature Conservancy [unpaginated].

1998, Freshwater mussel survey of the St. Joseph River drainage, exclusive of Fish Creek: Indiana Chapter of The Nature Conservancy, appendixes A-D.

\section{Additional Information}

For additional information about the USGS and its programs, contact

\author{
U.S. Geological Survey \\ District Chief \\ 6480 Doubletree Ave. \\ Columbus, $\mathrm{OH} 43229-1111$ \\ Email: dc_oh@usgs.gov
}

Phone: (614) 430-7700

Fax: (614) 430-7777

\section{Selected Web sites on freshwater mussels}

\author{
Illinois Natural History Survey Mollusk Collection \\ http://www.inhs.uiuc.edu/cbd/collections/mollusk.html
}

America's Mussels: Silent Sentinels

http://www.fws.gov/r3pao/eco_serv/endangrd/clams/mussels.html

American Freshwater Mussels (by Tom Watters)

http://erato.acnatsci.org/conchnet/uniowhat.html 